(c) American Dairy Science Association, 2006.

\title{
Relationships Among Manure Nitrogen Output and Dietary and Animal Factors in Lactating Dairy Cows
}

\author{
T. Yan, ${ }^{1}$ J. P. Frost, R. E. Agnew, R. C. Binnie, and C. S. Mayne \\ Agri-Food and Biosciences Institute, Hillsborough, Co. Down, UK
}

\begin{abstract}
A large data set derived from total diet digestibility assessments on lactating dairy cows (535 HolsteinFriesian and 29 Norwegian) was used to examine effects of dietary and animal factors on manure (feces and urine) nitrogen (N) output and to develop mitigation strategies and prediction equations for manure $\mathrm{N}$ output in lactating dairy cows. Manure $\mathrm{N}$ output was positively and significantly related to live weight, milk yield, dietary crude protein (CP) concentration, dry matter intake, and $\mathrm{N}$ intake. Reducing the dietary $\mathrm{CP}$ concentration or increasing the milk yield decreased manure $\mathrm{N}$ output per kilogram of milk yield. Prediction equations for manure $\mathrm{N}$ output using live weight and milk yield, either alone or combined, had relatively low $\mathrm{R}^{2}(0.227$ to 0.474$)$ and large standard error (70.6 to 85.6) values. Addition of dietary CP concentration to these relationships considerably increased $R^{2}$ to 0.754 and reduced the standard error to 48.2. Relating manure $\mathrm{N}$ output to $\mathrm{N}$ intake produced a very high $\mathrm{r}^{2}$ (0.901) and a very low standard error (30.6). The addition of live weight and milk yield to this relationship as supporting predictors only marginally increased $\mathrm{R}^{2}$ to 0.910 and reduced the standard error to 29.3. The internal validation of these equations revealed that use of $\mathrm{N}$ intake as the primary predictor produced a very accurate prediction of manure $\mathrm{N}$ output. In situations in which data on $\mathrm{N}$ intake are not available, prediction equations based on dietary $\mathrm{CP}$ concentration, live weight, and milk yield together can produce a relatively accurate assessment of manure $\mathrm{N}$ output.
\end{abstract}

Key words: dairy cow, manure nitrogen output, nitrogen intake, prediction equation

\section{INTRODUCTION}

Nitrogen is of primary environmental concern at present because of losses of ammonia to the air and nitrate contamination of surface water and groundwa-

Received October 18, 2005.

Accepted April 16, 2006.

${ }^{1}$ Corresponding author: tianhai.yan@afbini.gov.uk ter (Tamminga, 1992; Van Horn et al., 1994). Every year large amounts of $\mathrm{N}$ are brought onto dairy farms, and much of this $\mathrm{N}$ remains on the farm rather than being incorporated into milk, animal tissue, and crops that are sold off the farm (Korevaar, 1992; Klausner, 1993). The overall efficiency of utilization of dietary $\mathrm{N}$ in European dairy farming was estimated to be less than $20 \%$ and in many situations is still decreasing (Bruchem et al., 1991). Consequently, dairy production contributes to environmental pollution from $\mathrm{N}$ as ammonia $\mathrm{N}$ and nitrous oxides in air and as nitrate in soil and groundwater (Tamminga, 1992). In 1991, the European Union introduced the Nitrates Directive, (European Union, 1991) which aims to prevent the pollution of groundwater and surface water by nitrates arising from agricultural sources. The Directive stipulates mandatory measures that must be included in an action program, one of which involves a limit on the amount of livestock manure (feces and urine) that may be applied to land each year, set at $170 \mathrm{~kg}$ of organic $\mathrm{N}$ (manure $\mathrm{N}$ ) per hectare. This limit will have very significant implications for stocking rates on livestock farms. Therefore, there is increasing interest in developing approaches to mitigate manure $\mathrm{N}$ output in animal production. From 1990 to 2002, a large number of lactating dairy cows were used in total diet digestibility measurements at the Agricultural Research Institute of Northern Ireland. The objectives of the present study were to use these digestibility data to examine effects of dietary and animal factors on the efficiency of utilization of dietary $\mathrm{N}$ and then to develop mitigation strategies and prediction equations for manure $\mathrm{N}$ output in lactating dairy cows.

\section{MATERIALS AND METHODS}

\section{Animals and Diets}

The data set used in the present study was obtained from 564 lactating dairy cows (535 Holstein-Friesian and 29 Norwegian breed) in 26 total diet digestibility studies undertaken at the Agricultural Research Institute of Northern Ireland from 1990 to 2002. The animals used were of various genetic merits (low to high) and different stages of lactation, with milk yields during 
Table 1. Summary statistics of animal and dietary variables and nitrogen intake, excretion, and retention data used in model development

\begin{tabular}{|c|c|c|c|c|c|}
\hline Variable & No. & Mean & SD & Minimum & Maximum \\
\hline \multicolumn{6}{|l|}{ Animal and dietary data } \\
\hline Age, mo & 477 & 55 & 21.4 & 25 & 126 \\
\hline Live weight, $\mathrm{kg}$ & 564 & 564 & 65.3 & 385 & 781 \\
\hline $\mathrm{BCS}$ & 248 & 2.57 & 0.454 & 1.75 & 4.25 \\
\hline Lactation number & 477 & 3 & 1.8 & 1 & 9 \\
\hline DIM & 477 & 151 & 68.8 & 16 & 422 \\
\hline Milk yield, kg/d & 564 & 21.4 & 6.61 & 6.1 & 49.1 \\
\hline Total DMI, kg/d & 564 & 16.4 & 3.02 & 7.5 & 24.3 \\
\hline Forage proportion, $\mathrm{g} / \mathrm{kg}$ of $\mathrm{DM}$ & 564 & 579 & 183.4 & 211 & 1,000 \\
\hline $\mathrm{CP}$ concentration, $\mathrm{g} / \mathrm{kg}$ of $\mathrm{DM}$ & 564 & 183 & 25.9 & 106 & 271 \\
\hline \multicolumn{6}{|l|}{ Nitrogen utilization data, g/d } \\
\hline Nitrogen intake & 564 & 486 & 129.6 & 155 & 874 \\
\hline Fecal nitrogen & 564 & 142 & 36.1 & 48 & 241 \\
\hline Urine nitrogen & 564 & 209 & 69.1 & 70 & 452 \\
\hline Milk nitrogen & 564 & 109 & 33.0 & 24 & 231 \\
\hline Retained nitrogen & 564 & 26 & 35.0 & -75 & 150 \\
\hline
\end{tabular}

digestibility measurements ranging from 6.1 to $49.1 \mathrm{~kg} /$ d. A total of 477 cows had records of lactation number and DIM at the commencement of digestibility studies, of which 92,152 , and 233 cows were in the first, second, and third lactation or above, respectively; and 118, 303, and 56 cows were in 0 to 100,101 to 200 , and above 200 DIM, respectively. Table 1 presents the mean, standard deviation, and range of data for age, live weight, BCS, lactation number, and DIM.

A total of 71 perennial ryegrass silages, 3 types of fresh grass, and one fodder beet were examined over the 26 experiments. The grass silages encompassed primary growth and first and second regrowth material. The grass was either unwilted or wilted prior to ensiling and ensiled with or without application of silage additives. A total of 49 cows were offered forage as the sole diet, but otherwise all other cattle $(n=515)$ were offered forages with a range of proportions of concentrates from 211 to 876 (g/kg of DM) with a mean of 539 (SD 135.4). The concentrates used in each of the studies included a mineral-vitamin supplement and some of the following ingredients: cereal grains (barley, wheat, or corn), byproducts (corn gluten meal, molassed or unmolassed sugar-beet pulp, citrus pulp, or molasses), and protein supplements (fish meal, soybean meal, or rapeseed meal). The concentrate portion of the diet was offered either in a complete diet mixed with the grass silage or as a feed separate from the silage. All animals were offered either silage or the complete diet ad libitum. Data on the mean, standard deviation, and range for DMI, proportion of dietary forage, and dietary CP concentration are presented in Table 1.

\section{Digestibility Measurements}

Prior to commencing the digestibility studies, all cows were housed in loose housing using cubicles and were offered experimental diets for at least $20 \mathrm{~d}$. Animals had free access to water. Animals were then transferred to metabolism units and housed for $8 \mathrm{~d}$ with total collection of feces and urine during the final $6 \mathrm{~d}$. Feces and urine outputs were recorded and sampled daily as a

Table 2. Correlation coefficients $(r)$ for the linear relationships between nitrogen variables and dietary and animal factors ${ }^{1}$

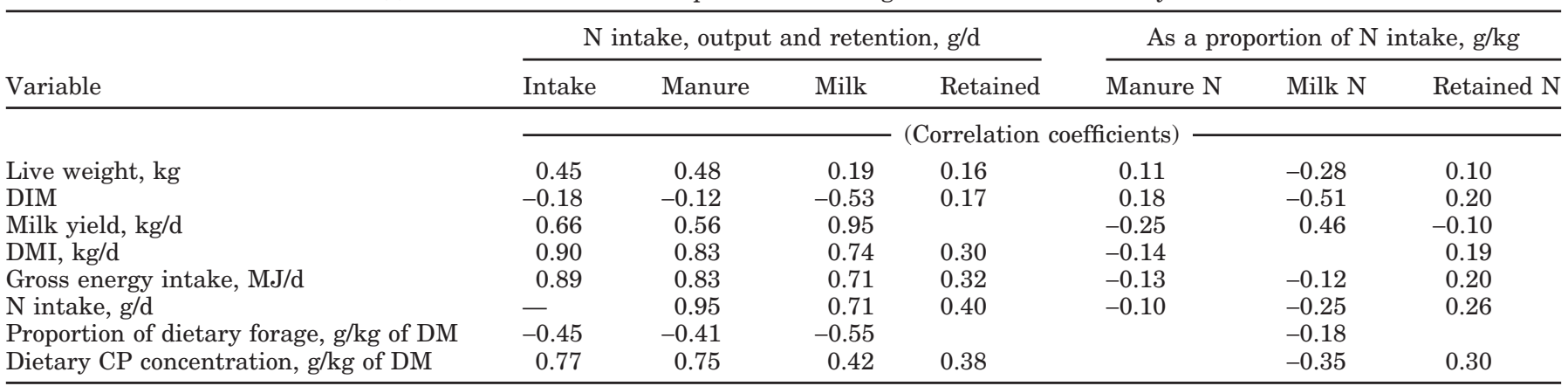

${ }^{1}$ When $\mathrm{r}=[0.10]$ to [0.11], $P<0.05 ; \mathrm{r}=[0.12]$ to [0.13], $P<0.01 ; \mathrm{r} \geq[0.13], P<0.001$. 
Table 3. Linear and multiple prediction equations for manure nitrogen $(\mathrm{N})$ output $(\mathrm{g} / \mathrm{d})$ using nitrogen intake, live weight, and milk yield as primary predictors ${ }^{1}$

\begin{tabular}{|c|c|c|c|}
\hline Equation & $\mathrm{R}^{2}$ & $\mathrm{SE}$ & $\begin{array}{l}\text { Equation } \\
\text { no. }\end{array}$ \\
\hline Manure $\mathrm{N}$ output $=0.711_{(0.055)} \mathrm{LW}-51_{(31)}$ & 0.227 & 85.6 & 1 \\
\hline $8.283_{(0.514)} \mathrm{MY}+174_{(12)}$ & 0.315 & 80.5 & 2 \\
\hline$\left[0.705_{(0.049)}-0.00017_{(0.00003)} \mathrm{F} / \mathrm{T}\right] \mathrm{LW}+6.163_{(0.502)} \mathrm{MY}-122_{(26)}$ & 0.499 & 68.9 & 4 \\
\hline$\left[0.00287_{(0.00012)} \mathrm{LW}+0.02429_{(0.00161)} \mathrm{MY}\right] \mathrm{CPc}-44_{(11)}$ & 0.754 & 48.2 & 5 \\
\hline $0.713_{(0.010)} \mathrm{NI}+5_{(5)}$ & 0.901 & 30.6 & $6 a$ \\
\hline $0.749_{(0.014)} \mathrm{NI}+0.065_{(0.022)} \mathrm{LW}-1.515_{(0.255)} \mathrm{MY}-17_{(11)}$ & 0.910 & 29.3 & 9 \\
\hline
\end{tabular}

${ }^{1}$ Values in subscript parentheses are SE. CPc = dietary CP concentration (g/kg of DM); LW = live weight (kg); MY = milk yield (kg/d); F/ $\mathrm{T}=$ proportion of dietary forage $(\mathrm{g} / \mathrm{kg}$ of $\mathrm{DM})$.

proportion (5\%) of total excretion of feces (by weight) and urine (by volume). The 6-d samples of feces and urine were mixed separately and a representative sample was taken for analysis as follows: Feces samples were analyzed for DM, N, gross energy (GE), ADF, $\mathrm{NDF}$, and ash concentrations, and urine samples were analyzed for GE and N concentrations. During the $8 \mathrm{~d}$ in metabolism units, total food intake was recorded daily. The forage was sampled daily for oven DM determination and the dried sample was bulked over the final $6 \mathrm{~d}$ for determination of $\mathrm{ADF}$, NDF, and ash concentrations. With grass and fodder beet, combined dried samples were also used to determine CP and GE concentrations. With grass silages, fresh samples were taken daily for determination of toluene $\mathrm{DM}, \mathrm{pH}, \mathrm{CP}$, ammonia N, GE, lactic acid, VFA, ethanol, and propanol concentrations. Samples of concentrates were taken daily and analyzed for oven DM, CP, GE, ADF, NDF, and ash concentrations. The details on feces and urine collection and methods used for analysis of feeds, feces, and urine samples were as described by Mayne and Gordon (1984). Crude protein concentration was determined as Kjeldahl $\mathrm{N} \times 6.25$. Silage $\mathrm{pH}$ was determined using a Corning $113 \mathrm{pH}$ meter, and ammonia was assayed by bringing the alkalinity of the aqueous extract to $\mathrm{pH}$ 10 and using an Orion 95-12-00 ammonia sensing gas electrode. Volatile fatty acids, lactic acid, ethanol, and propanol concentrations in silage samples were analyzed by GLC using a PerkinElmer gas chromatograph (PerkinElmer, Wellesley, MA) having a column packed with 80/120 Carbopack B-DA-4\% Carbowax, 20 m (Supelco, Bellefonte, PA).

Milk yields were recorded daily and milk samples were taken during the morning and afternoon milking, starting at $0500 \mathrm{~h}$ and $1630 \mathrm{~h}$ respectively, during the $8 \mathrm{~d}$ in metabolism units, and were analyzed for fat and lactose concentrations using a MilkoScan model 605 (Foss Electric, Hillerød, Denmark), and protein concen- tration as Kjeldahl $\mathrm{N} \times 6.38$. Live weight was determined on the first and last days in metabolism units. Body condition score was determined on the first day in metabolism units using the method described by Mulvanny (1977), with 5 categories from 1 (very thin) to 5 (very fat). Data on the mean, standard deviation, and range for $\mathrm{N}$ intake and outputs in feces, urine, and milk and retained $\mathrm{N}$ are presented in Table 1.

\section{Statistical Analyses}

The correlation coefficients, presented in Table 2, were determined using the linear regression between $\mathrm{N}$ intake and output and dietary and animal factors. Linear and multiple regression models were used to develop prediction equations for manure $\mathrm{N}$ output. Two sets of variables were used to develop these equations (i.e., animal and dietary variables with or without total $\mathrm{N}$ intake), because $\mathrm{N}$ intake may not always be available in commercial practice.

An internal evaluation was undertaken to validate the prediction equations for manure $\mathrm{N}$ output by dividing the data set into 2 subsets, one-third $(\mathrm{n}=188)$ and two-thirds $(\mathrm{n}=376)$ of the data, according to the range of $\mathrm{N}$ intake. Two-thirds of the data were used to develop relationships similar to those developed using the whole data set. These new equations were then evaluated using the remaining one-third of the data. Prediction accuracy of relationships was examined using the mean-square prediction error (MSPE; Equation a):

$$
\operatorname{MSPE}=\frac{1}{\mathrm{n}} \Sigma(P-A)^{2}
$$

where $P$ or $A$ is the predicted or actual manure N output; $\mathrm{n}$ is the number of pairs of values of $P$ and $A$ compared. Mean prediction error (MPE), rather than MSPE, was 
used to describe the prediction accuracy $(\mathrm{MPE}=$ $\sqrt{\mathrm{MSPE}} / \bar{A}, \bar{A}=A / \mathrm{n}$ ).

All analysis for the development of prediction equations for manure N output was performed using Genstat 5, release 4.1, third edition (Lawes Agricultural Trust, Rothamsted, UK).

\section{RESULTS}

\section{Data Set}

The data set used in the present study represented a very wide range in dietary and animal variables (Table 1). These variations resulted in large differences in the efficiencies of $\mathrm{N}$ utilization: fecal $\mathrm{N}: \mathrm{N}$ intake from 14 to $46 \%$ (mean $30 \%$, SD 4.2), urinary $\mathrm{N}: \mathrm{N}$ intake from 28 to $62 \%$ (mean $43 \%$ SD, 6.7), milk N:N intake from 7 to $41 \%$ (mean $23 \%$, SD 4.9), and retained N:N intake from -28 to $28 \%$ (mean 5\%, SD 7.1).

\section{Relationships Between N Data and Animal and Dietary Variables}

The correlation coefficients (r) in the linear relationships between $\mathrm{N}$ intake and output and between $\mathrm{N}$ utilization variables and animal and dietary data are presented in Table 2. Nitrogen intake and outputs in manure and milk were all positively related to live weight, milk yield, DMI, $\mathrm{N}$ intake (with $\mathrm{N}$ outputs in manure and milk only), GE intake, and dietary $\mathrm{CP}$ concentration $(P<0.001)$, with $\mathrm{r}$ values ranging from 0.19 to 0.95 , and negatively related to DIM and proportion of dietary forage $(P<0.01)$. The $\mathrm{r}$ values in the relationships of manure $\mathrm{N}$ output were highest with $\mathrm{N}$ intake (0.95), followed by DMI (0.83), GE intake (0.83), and dietary $\mathrm{CP}$ concentration (0.75); relatively low with milk yield (0.56), live weight (0.48), and proportion of dietary forage $(-0.41)$; and lowest with DIM $(-0.12)$. There were positive relationships between retained $\mathrm{N}$ and live weight, DIM, DMI, GE intake, $\mathrm{N}$ intake, and dietary $\mathrm{CP}$ concentration $(P<0.001)$. The $\mathrm{r}$ values in the relationships of these dietary and animal variables with $\mathrm{N}$ outputs in manure and milk and retained $\mathrm{N}$ as a proportion of $\mathrm{N}$ intake were small even when the relationships were significant $(P<0.05)$, with the exception that $\mathrm{r}$ values in the relationships between milk $\mathrm{N}$ output as a proportion of $\mathrm{N}$ intake and DIM $(-0.51)$ and milk yield $(0.46)$ were relatively high.

\section{Prediction Equations for Manure N Output}

The linear and multiple prediction equations for manure $\mathrm{N}$ output developed in the present study are presented in Table 3, and the relationships between ma- nure $\mathrm{N}$ output and $\mathrm{N}$ intake, live weight, and milk yield are presented in Figure 1. All relationships were significant $(P<0.001)$ and each predictor had a significant effect on the relationship $(P<0.001)$. The $\mathrm{r}^{2}$ values in the linear relationship between manure $\mathrm{N}$ output and live weight $(0.227)$ or milk yield $(0.315)$ were low and standard error values were high (85.6 or 80.5 ; Equations 1 or 2); even when using both variables as predictors, the $\mathrm{R}^{2}$ value was still relatively low (0.474) and the standard error value was high (70.6; Equation 3 ). Addition of the proportion of dietary forage to Equation 3 marginally increased the $R^{2}$ value to 0.499 , and the standard error value reduced to 68.9 (Equation 4). However, when dietary CP concentration was added to Equation 3, the $\mathrm{R}^{2}$ value was considerably increased to 0.754 and the standard error value reduced to 48.2 (Equation 5).

The best single predictor for manure $\mathrm{N}$ output in lactating dairy cows was $\mathrm{N}$ intake; the $\mathrm{r}^{2}$ value in the linear relationship between manure $\mathrm{N}$ output and $\mathrm{N}$ intake was very high (0.901) and the standard error value was very low (30.6; Equation $6 a$ ). The omission of the constant had no effect on $\mathrm{r}^{2}$ and standard error values (Equation 6b). Addition of live weight and milk yield to Equation 6a had only small effects on $R^{2}$ and standard error values (Equations 7 to 9), although each supporting predictor had a significant effect on the relationship between manure $\mathrm{N}$ output and $\mathrm{N}$ intake $(P<$ 0.001). For example, including both milk yield and live weight along with $\mathrm{N}$ intake increased $\mathrm{R}^{2}$ values only from 0.901 to 0.910 and standard error values reduced from 30.6 to 29.3 (Equations 6a vs. 9).

\section{Effects of Animal and Dietary Variables on Manure N Output}

The animal and dietary variables examined included forage type, proportion of dietary forage, dietary $\mathrm{CP}$ concentration, animal breed, DIM, milk yield, and lactation number. The effects of these variables on manure $\mathrm{N}$ output were examined first by dividing the whole data set into a range of subsets within each variable and then by comparing the linear relationships of manure $\mathrm{N}$ output with $\mathrm{N}$ intake (with the slopes being fixed) between subsets within each variable. Results are presented in Table 4. The constants in the relationship between manure $\mathrm{N}$ output and $\mathrm{N}$ intake were similar between the 3 subsets within the proportion of dietary forage or lactation number. However, forage type, animal breed, DIM, and milk yield $(P<0.001)$ and dietary $\mathrm{CP}$ concentration $(P<0.05)$ affected the relationship between manure $\mathrm{N}$ output and $\mathrm{N}$ intake, with large differences in constants between the subsets within each variable. For example, fresh grass produced a 
Table 4. Effects of dietary and animal factors on the linear relationship between manure $\mathrm{N}$ output $(\mathrm{g} / \mathrm{d})$ and dietary $\mathrm{N}$ intake $(\mathrm{NI}, \mathrm{g} / \mathrm{d})^{1}$

\begin{tabular}{|c|c|c|c|c|}
\hline Variable & Equation & $\mathrm{r}^{2}$ & Significance & $\begin{array}{l}\text { Equation } \\
\text { no. }\end{array}$ \\
\hline $\begin{array}{l}\text { Forage type } \\
\text { Grass silage }(\mathrm{n}=514) \\
\text { Fresh grass }(\mathrm{n}=20) \\
\text { Fodder beet }(\mathrm{n}=30)\end{array}$ & 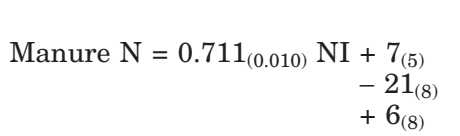 & 0.90 & $* * *$ & $\begin{array}{l}10 \mathrm{a} \\
10 \mathrm{~b} \\
10 \mathrm{c}\end{array}$ \\
\hline $\begin{array}{l}\text { Proportion of dietary forage, } \mathrm{g} / \mathrm{kg} \mathrm{DM} \\
<500(\mathrm{n}=211) \\
501-999(\mathrm{n}=304) \\
1,000(\mathrm{n}=49)\end{array}$ & Manure N=0.718 $\begin{aligned} \mathrm{N}(0.011) & \mathrm{NI} \\
& +0_{(6)} \\
& +3_{(5)} \\
& +6_{(6)}\end{aligned}$ & 0.90 & NS & $\begin{array}{l}11 \mathrm{a} \\
11 \mathrm{~b} \\
11 \mathrm{c}\end{array}$ \\
\hline $\begin{array}{l}\text { Dietary CP concentration, g/kg DM } \\
<160(\mathrm{n}=88) \\
160-200(\mathrm{n}=341) \\
>200(\mathrm{n}=135)\end{array}$ & Manure N=0.689 $\begin{aligned} \mathrm{N}(0.014) & \mathrm{NI} \\
+ & 11_{(5)} \\
& +14_{(7)} \\
& +25_{(9)}\end{aligned}$ & 0.90 & $*$ & $\begin{array}{l}12 \mathrm{a} \\
12 \mathrm{~b} \\
12 \mathrm{c}\end{array}$ \\
\hline $\begin{array}{l}\text { Animal breed } \\
\text { Holstein }(\mathrm{n}=535) \\
\text { Norwegian }(\mathrm{n}=29)\end{array}$ & 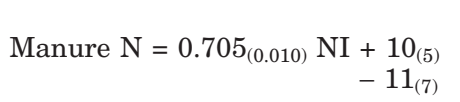 & 0.90 & $* * *$ & $\begin{array}{l}13 \mathrm{a} \\
13 \mathrm{~b}\end{array}$ \\
\hline $\begin{array}{l}\text { DIM } \\
<101(\mathrm{n}=118) \\
101-200(\mathrm{n}=303) \\
>200(\mathrm{n}=56)\end{array}$ & 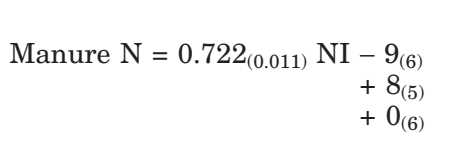 & 0.91 & $* * *$ & $\begin{array}{l}14 \mathrm{a} \\
14 \mathrm{~b} \\
14 \mathrm{c}\end{array}$ \\
\hline $\begin{array}{l}\text { Milk yield, } \mathrm{kg} / \mathrm{d} \\
>30(\mathrm{n}=57) \\
15-30(\mathrm{n}=431) \\
<15(\mathrm{n}=76)\end{array}$ & 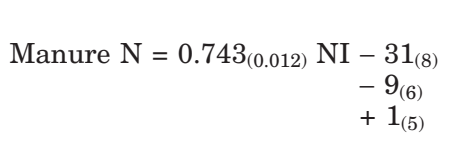 & 0.91 & $* * *$ & $\begin{array}{l}15 \mathrm{a} \\
15 \mathrm{~b} \\
15 \mathrm{c}\end{array}$ \\
\hline $\begin{array}{l}\text { Lactation number } \\
\text { First }(\mathrm{n}=92) \\
\text { Second }(\mathrm{n}=152) \\
\text { Third or above }(\mathrm{n}=233)\end{array}$ & 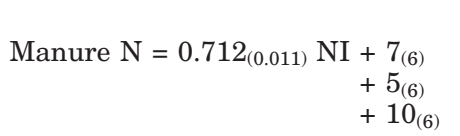 & 0.90 & NS & $\begin{array}{l}16 \mathrm{a} \\
16 \mathrm{~b} \\
16 \mathrm{c}\end{array}$ \\
\hline
\end{tabular}

${ }^{1}$ The slopes were a common value selected by the statistical program within each variable and values in subscript parentheses are SE. NS = not significant. $* P<0.05 ; * * * P<0.001$.

greater constant than grass silage, Holstein-Friesian cows had a greater constant than Norwegian cows, and midlactation animals (101 to $200 \mathrm{DIM})$ had a greater constant than early-lactation animals ( $<101$ DIM $)$. Similarly, the constant increased linearly with increasing dietary $\mathrm{CP}$ concentration from below 160 to more than $200 \mathrm{~g} / \mathrm{kg}$ of DM, whereas it reduced linearly with increasing milk yield from below 15 to more than $30 \mathrm{~kg} / \mathrm{d}$.

\section{Internal Validation of Prediction Equations for Manure N Output}

The equations developed (Equations i to viii) using two-thirds of the present data set are presented in Table 5 and are very similar to those presented in Table 3 using the whole data set. These new equations were validated using the remaining one-third of the data set. Results of this internal validation are presented in Table 6 . The mean predicted manure $\mathrm{N}$ outputs from all 8 equations (Equations i to viii) were very close to the actual data. However, the equations using live weight and milk yield as predictors, either alone or combined (Equations i to iii), produced very large MPE values (0.20 to 0.25$)$ and low $\mathrm{r}^{2}$ values (0.22 to 0.47$)$ in the relationship between predicted and actual manure $\mathrm{N}$ output. When dietary CP concentration was added to the equation using live weight and milk yield as predictors (Equation iv), MPE was considerably reduced to 0.13 and $r^{2}$ increased to 0.80 . However, the best prediction accuracy was obtained using $\mathrm{N}$ intake as a sole or primary predictor. The prediction using $\mathrm{N}$ intake as the sole predictor (Equation v) produced a very small MPE value (0.08) and a very high $r^{2}$ value (0.91) in the relationship between predicted and actual manure $\mathrm{N}$ output. These MPE and $\mathrm{r}^{2}$ values were almost unchanged when live weight and milk yield were added as supporting predictors (Equations v vs. vi to viii).

Residual plots were also used to evaluate the prediction accuracy by plotting the predicted manure $\mathrm{N}$ output ( $\mathrm{x}$ axis) against the corresponding residual manure $\mathrm{N}$ output of predicted minus actual (y axis). Results are presented in Table 6 and Figure 2. The residual plots from equations using live weight and milk yield as predictors, either alone or combined (Equations i to iii), were scattered, whereas they were relatively uniformly 


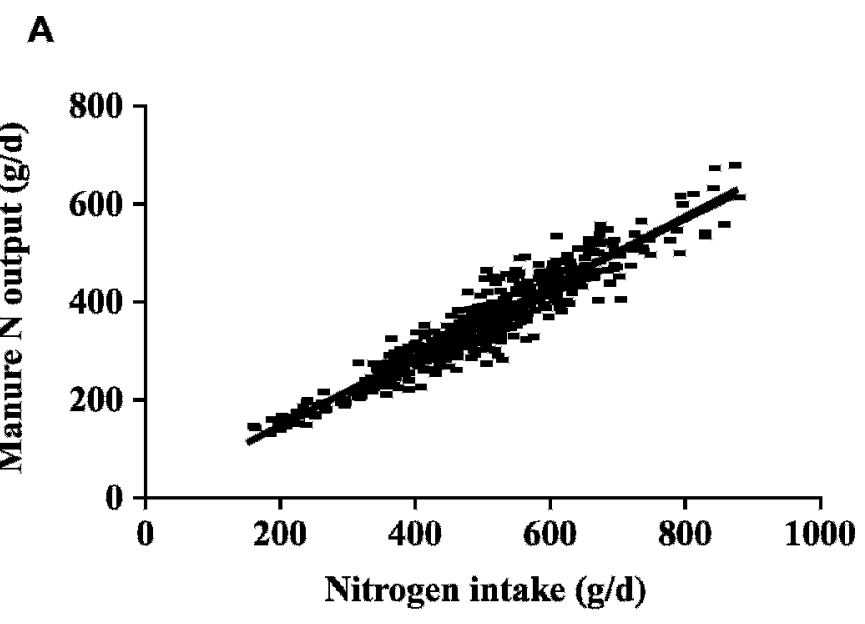

B

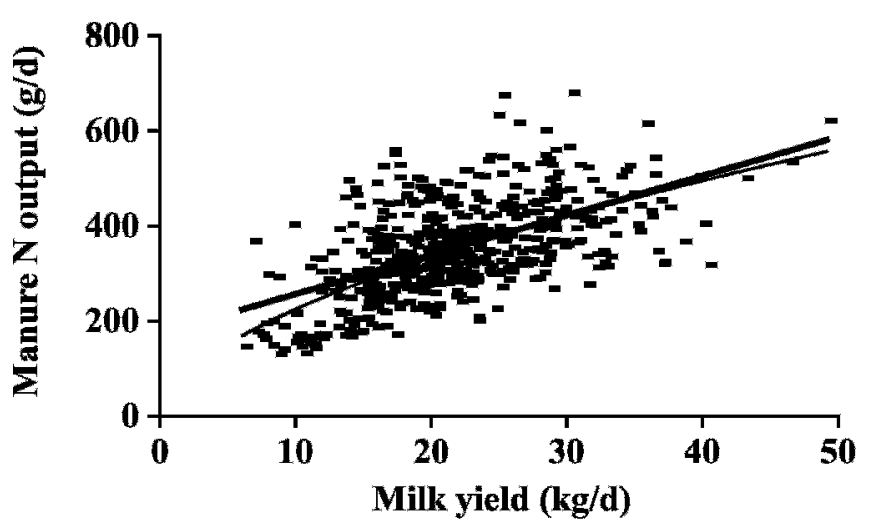

C

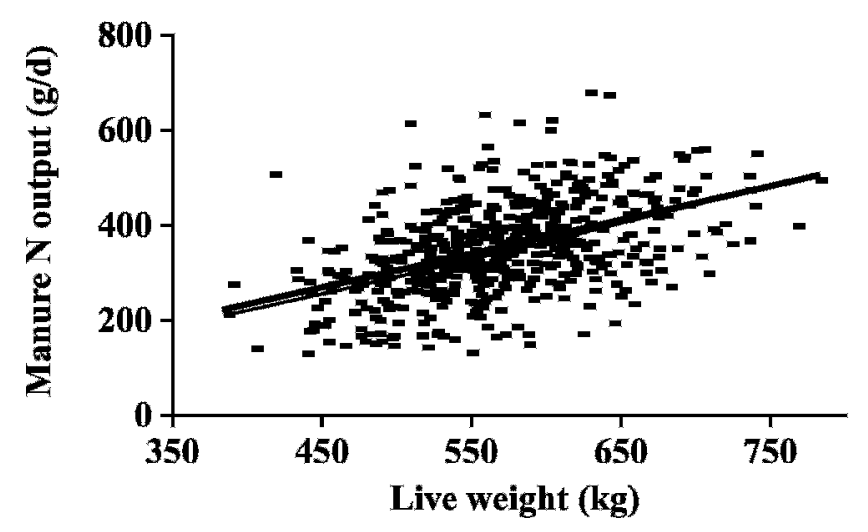

Figure 1. Relationships between manure nitrogen output and nitrogen intake (A), milk yield (B), and live weight (C) of lactating dairy cows $(n=564)$.

distributed around the zero line with Equation vi when dietary CP concentration was used together with live weight and milk yield as predictors. However, the best distribution of the residual plots was derived from the prediction using $\mathrm{N}$ intake as a sole or primary predictor
(Equations $\mathrm{v}$ to viii), with the vast majority of the residual plots distributed uniformly around the zero line. The standard deviation values and the ranges of the residual manure $\mathrm{N}$ outputs, as presented in Table 6 , were therefore much smaller with Equations v to viii than Equations i to iii, and with Equation iv between these 2 group equations. These results are in accordance with MPE and $r^{2}$ in the relationship between predicted and actual manure $\mathrm{N}$ outputs, as reported previously.

\section{DISCUSSION}

In comparison with other review papers published recently (Wilkerson et al., 1997; Castillo et al., 2000; Nennich et al., 2005), the present study contains a number of unique aspects. First, the diets used in the present study were primarily based on grass silages, in contrast to previous publications that were mainly based on nongrass silage diets (Wilkerson et al., 1997; Nennich et al., 2005). Second, the present study examined the relationships between $\mathrm{N}$ utilization data and a number of dietary and animal factors (some results are presented in Table 2). From the comparison of correlation coefficients ( $\mathrm{r}$ values), $\mathrm{N}$ intake was found to be the best variable to describe manure $\mathrm{N}$ output, and the relationship between manure $\mathrm{N}$ and live weight or milk yield was very poor. This suggests that live weight is not a good predictor of manure $\mathrm{N}$ output in lactating dairy cows, although both Smith and Frost (2000) and the American Society of Agricultural Engineers (ASAE, 2001) have proposed the use of live weight to predict manure $\mathrm{N}$ output for dairy cows. Third, a linear regression approach was used to examine the effects of some dietary and animal factors on the efficiency of $\mathrm{N}$ use for production by dividing the whole data set into a number of sub-data sets within each variable (Table 4). Based on these results, a number of mitigation strategies for manure $\mathrm{N}$ output are presented in the next subsection. Fourth, 2 comprehensive sets of prediction equations for manure $\mathrm{N}$ output were developed, one based on live weight, milk yield, and dietary CP concentration, and the other based on $\mathrm{N}$ intake. This is in contrast to other recent publications (Wilkerson et al., 1997; Castillo et al., 2000; Nennich et al., 2005), which developed a relatively limited number of relationships. The larger range of equations developed in the present study gives a greater selection of models for use in practice, according to the availability of dietary and animal data. Furthermore, the equations developed in the present study were internally validated, whereas Wilkerson et al. (1997), Castillo et al. (2000), or Nennich et al. (2005) provided no validation for their models. The present validation indicated that $\mathrm{N}$ intake alone 
Table 5. Internal validation: linear and multiple prediction equations for manure nitrogen $(\mathrm{N})$ output (g/ d) developed using two thirds of the data set $(n=376)^{1}$

\begin{tabular}{|c|c|c|c|}
\hline Equation & $\mathrm{R}^{2}$ & SE & $\begin{array}{l}\text { Equation } \\
\text { no. }\end{array}$ \\
\hline Manure $\mathrm{N}$ output $=0.701_{(0.066)} \mathrm{LW}-46_{(38)}$ & 0.232 & 84.8 & $\mathrm{i}$ \\
\hline $7.960_{(0.630)} \mathrm{MY}+181_{(14)}$ & 0.298 & 81.0 & ii \\
\hline $0.618_{(0.055)} \mathrm{LW}+7.256_{(0.549)} \mathrm{MY}-155_{(32)}$ & 0.477 & 70.1 & iii \\
\hline$\left[0.00287_{(0.00015)} \mathrm{LW}+0.02328_{(0.00201)} \mathrm{MY}\right] \mathrm{CPc}-41_{(13)}$ & 0.734 & 49.9 & iv \\
\hline $0.710_{(0.013)} \mathrm{NI}+7_{(6)}$ & 0.894 & 31.4 & $\mathrm{v}$ \\
\hline $0.686_{(0.014)} \mathrm{NI}+0.105_{(0.027)} \mathrm{LW}-41_{(14)}$ & 0.899 & 30.8 & vi \\
\hline $0.766_{(0.016)} \mathrm{NI}-1.688_{(0.310)} \mathrm{MY}+16_{(6)}$ & 0.902 & 30.3 & vii \\
\hline $0.742_{(0.018)} \mathrm{NI}+0.072_{(0.027)} \mathrm{LW}-1.468_{(0.318)} \mathrm{MY}-18_{(14)}$ & 0.904 & 30.0 & viii \\
\hline
\end{tabular}

${ }^{1}$ Values in subscript parentheses are $\mathrm{SE} . \mathrm{CPc}=$ dietary $\mathrm{CP}$ concentration $(\mathrm{g} / \mathrm{kg} \mathrm{DM})$; LW = live weight $(\mathrm{kg}) ; \mathrm{MY}=$ milk yield $(\mathrm{kg} / \mathrm{d})$.

could produce a very accurate prediction of manure $\mathrm{N}$ output in lactating dairy cows and that the addition of live weight and milk yield as supporting predictors had little improvement on the prediction accuracy.

The present data set is comparable to a number of recently published data sets (e.g., Wilkerson et al., 1997; Castillo et al., 2000; Nennich et al., 2005). For example, the present study reported a manure $\mathrm{N}$ output of $72.2 \%$ of $\mathrm{N}$ intake from the linear regression $\left(\mathrm{r}^{2}=\right.$ 0.901 ) in lactating dairy cows with an average milk yield of $21.4 \mathrm{~kg} / \mathrm{d}$. This value is similar to that $(72 \%)$ reported by Castillo et al. (2000) in a review of 580 lactating dairy cows and 90 treatments published in the literature, but milk yield, animal and dietary data, or sources of data were not reported in the paper. Wilkerson et al. (1997) reported details of the analysis of a large data set containing 994 lactating dairy cows obtained from the Energy Metabolism Unit in Beltsville, Maryland. Manure N:N intake was calculated from $\mathrm{N}$ intake and output in feces and urine as being $73 \%$ for cows with an average milk yield of $14 \mathrm{~kg} / \mathrm{d}$, and $69 \%$ for cows with an average milk yield of $29 \mathrm{~kg} / \mathrm{d}$. Hence, these data indicate a higher efficiency of $\mathrm{N}$ use for lactation with higher yielding cows. Nennich et al. (2005) reported a large data set of lactating dairy cows, obtained from 4 universities in the United States, with the majority of data collected at Washington State University. From the reported total DMI $(n=553)$, dietary CP concentration $(\mathrm{n}=529)$, and manure $\mathrm{N}$ output $(\mathrm{n}=$ 529 ), manure $\mathrm{N}$ output was calculated as being approximately $72.2 \%$ of total $\mathrm{N}$ intake, with an average milk yield of $31.4 \mathrm{~kg} / \mathrm{d}$. This value was the same as that obtained in the present study, but higher than that reported by Wilkerson et al. (1997) with high-yielding cows, although milk yield $(31.4 \mathrm{~kg} / \mathrm{d})$ in the study by Nennich et al. (2005) was much higher than in the present study $(21.4 \mathrm{~kg} / \mathrm{d})$ and in the study of Wilkerson et al. $(1997 ; 29 \mathrm{~kg} / \mathrm{d})$. The lower efficiency of $\mathrm{N}$ utilization for production in the study by Nennich et al. (2005) with high-yielding cows may be due to use of ruminally and duodenally cannulated cows, rather than cows from production experiments.

\section{Mitigation Approaches to Reduce Manure N Output}

In the present study, the effect of a number of dietary and animal factors on manure $\mathrm{N}$ output were evaluated by comparing the linear relationships of manure $\mathrm{N}$ output with total $\mathrm{N}$ intake (with the slopes being fixed) between subsets within each variable, when the whole

Table 6. Internal validation using one-third of the present data $(n=188)$ and equations ${ }^{1}$ developed from the remaining two-thirds of data $(\mathrm{n}=376)$

\begin{tabular}{|c|c|c|c|c|c|c|c|c|c|}
\hline \multirow[b]{2}{*}{ Equation } & \multicolumn{3}{|c|}{ Manure $\mathrm{N}$ output, g/d } & \multirow[b]{2}{*}{$\mathrm{MPE}^{2}$} & \multirow[b]{2}{*}{$\mathrm{SE}$} & \multicolumn{4}{|c|}{ Predicted - actual manure N, g/d } \\
\hline & Predicted & Actual & $\mathrm{r}^{2}$ & & & Mean & SD & Min & Max \\
\hline i & 346 & 349 & 0.22 & 0.25 & 39.0 & -5 & 87.2 & -306 & 217 \\
\hline ii & 352 & & 0.35 & 0.23 & 42.2 & 1 & 79.9 & -293 & 166 \\
\hline iii & 346 & & 0.47 & 0.20 & 49.3 & -4 & 71.7 & -252 & 159 \\
\hline iv & 345 & & 0.80 & 0.13 & 38.0 & -5 & 44.7 & -164 & 129 \\
\hline $\mathrm{v}$ & 353 & & 0.91 & 0.08 & 27.4 & 2 & 28.9 & -100 & 60 \\
\hline vi & 351 & & 0.92 & 0.08 & 27.2 & 1 & 28.7 & -103 & 58 \\
\hline vii & 353 & & 0.92 & 0.08 & 26.3 & 3 & 27.8 & -105 & 68 \\
\hline viii & 352 & & 0.92 & 0.08 & 26.2 & 2 & 27.7 & -106 & 64 \\
\hline
\end{tabular}

${ }^{1}$ All equations are presented in Table 5 .

${ }^{2} \mathrm{MPE}=$ Mean prediction error. 

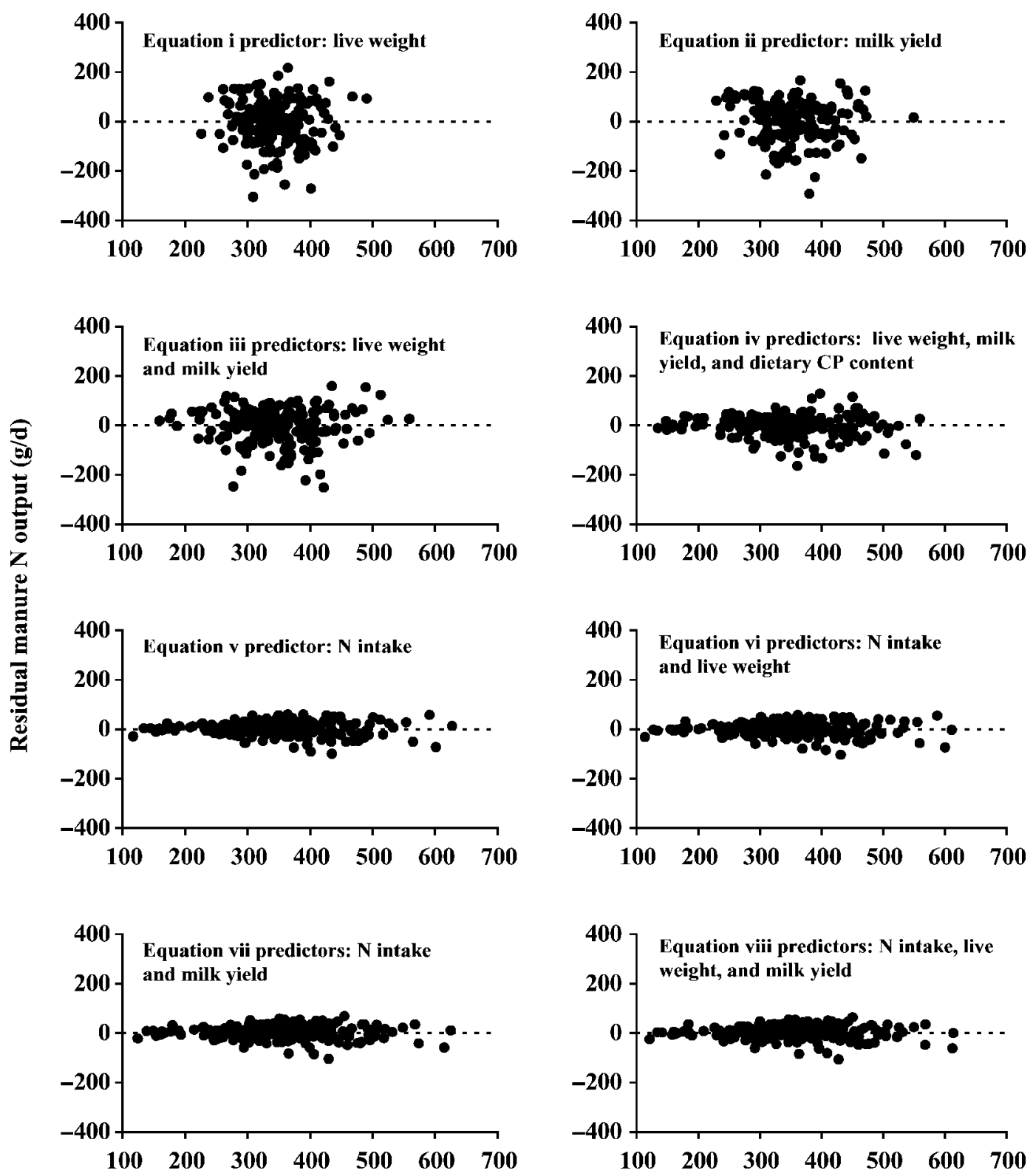

Predicted manure N output (g/d)

Figure 2. Internal validation: predicted manure nitrogen output (x axis) versus residual manure nitrogen output (predicted minus actual) using one-third of the present data set $(n=188)$ and equations developed from the remaining two-thirds of the data set $(n=376)$.

data set was divided into a range of subsets within each variable. Although the proportion of dietary forage and lactation number had no significant effects on the relationship, the constants in the relationships were significantly different between subsets within forage type, dietary CP concentration, animal breed, milk yield, and DIM, indicating these variables had significant effects on the relationship. This implies that it is possible to mitigate manure $\mathrm{N}$ output in lactating dairy cows by manipulating these factors.
For example, the evaluation of the effect of forage type in the present study revealed that cows offered fresh grass diets excreted less manure $\mathrm{N}$ than cows offered grass silage diets or fodder beet diets, because the former had a smaller constant in the relationship between manure $\mathrm{N}$ output and $\mathrm{N}$ intake. A similar result was also obtained when comparing Norwegian cows with Holstein-Friesian cows. However, caution should be taken when interpreting these results, because the data set on fresh grass was quite small $(\mathrm{n}=$ 
Table 7. Relationships between milk $\mathrm{N}: \mathrm{N}$ intake $(\mathrm{g} / \mathrm{kg})$, and dietary CP concentration (CPc, g/kg DM), DIM, and milk yield (MY, kg/d) ${ }^{1}$

\begin{tabular}{|c|c|c|c|}
\hline Equations & $\mathrm{r}^{2}$ & $\mathrm{SE}$ & $\begin{array}{l}\text { Equation } \\
\text { no. }\end{array}$ \\
\hline $\begin{aligned} \text { Milk N/N intake }= & -0.672_{(0.075)} \mathrm{CPc}+350_{(14)} \\
& -0.359_{(0.028)} \mathrm{DIM}+280_{(5)} \\
& 3.448_{(0.278)} \mathrm{MY}+153_{(6)}\end{aligned}$ & $\begin{array}{l}0.13 \\
0.26 \\
0.21\end{array}$ & $\begin{array}{l}46.1 \\
41.6 \\
43.7\end{array}$ & $\begin{array}{l}17 \\
18 \\
19\end{array}$ \\
\hline
\end{tabular}

${ }^{1}$ Values in subscript parentheses are SE.

20 vs. 514) and represented a much smaller range in $\mathrm{N}$ intake (206 to 603 vs. 155 to $874 \mathrm{~g} / \mathrm{d}$ ) when compared with grass silage. Similarly, the number of data points ( $\mathrm{n}=29$ vs. 535$)$ and range of $\mathrm{N}$ intake (181 to $568 \mathrm{vs.}$ 155 to $874 \mathrm{~g} / \mathrm{d}$ ) with Norwegian cows were much smaller than with Holstein-Friesian cows.

A decrease in $\mathrm{CP}$ concentration in the diet can be an effective approach to reduce the manure $\mathrm{N}$ output. As presented in Table 4, manure $\mathrm{N}$ output can be reduced by using diets containing lower $\mathrm{CP}$ contents. On the other hand, milk $\mathrm{N}$ output as a proportion of $\mathrm{N}$ intake $(\mathrm{g} / \mathrm{kg})$ was reduced by proportionately 0.672 with an increasing dietary CP concentration of $1 \mathrm{~g} / \mathrm{kg}$ of DM (Equation 17, Table 7). The reduction in proportional milk $\mathrm{N}$ output indicates an increase in manure $\mathrm{N}$ excretion as a proportion of $\mathrm{N}$ intake. Similar conclusions have been reported elsewhere (Hof and Tamminga, 1994; Børsting et al., 2003). To reduce manure $\mathrm{N}$ output in dairy cows, Kebreab et al. (2001) suggested that N intake should be less than $400 \mathrm{~g} / \mathrm{d}$ for average-yielding cows, and dietary $\mathrm{N}$ concentration should not exceed 30 $\mathrm{g} / \mathrm{kg}$ of DM (187.5 g of CP/kg of DM; Tamminga, 1992).

However, decreases in dietary CP concentration, when lower than animal requirements, especially rumen-degradable CP content, can restrict microbial activity in the rumen, consequently reducing food intake and milk yield (Agricultural Research Council, 1980). Therefore, animal productivity and health should be considered when developing mitigation strategies, because increasing animal productivity is also a mitigation approach to reduce manure $\mathrm{N}$ output per unit of production. In the present study, as presented in Table 4 , a high-yielding cow (over $30 \mathrm{~kg}$ of milk/d) may excrete less $\mathrm{N}$ in manure per kilogram of milk production than medium- and low-yielding cows (Equations 15a vs. 15b and 15c), although the lower manure $\mathrm{N}$ output with high-yielding cows may be partially derived from their mobilization of body tissue for milk production during the first few weeks of lactation. This is shown in Equations 18 and 19 (Table 7) when relating milk $\mathrm{N}$ output as a proportion of $\mathrm{N}$ intake to DIM and milk yield. These 2 relationships indicate that the milk N:N intake ratio $(\mathrm{g} / \mathrm{kg})$ can be reduced by proportionately 0.359 with each $1 \mathrm{~d}$ increase in milk or increased by propor- tionately 3.448 with each $1 \mathrm{~kg} / \mathrm{d}$ increase in milk yield. The proportional increase in milk $\mathrm{N}$ output indicates a reduction in manure $\mathrm{N}$ excretion as a proportion of $\mathrm{N}$ intake. The higher proportion of milk $\mathrm{N}$ output with high-yielding cows may reflect a greater efficiency of $\mathrm{N}$ utilization for milk production, but this is mainly derived from a lower proportion of $\mathrm{N}$ intake required for maintenance with high-yielding compared with lowyielding cows. Wilkerson et al. (1997) reported that the milk N:N intake ratio was lower for cows with an average milk yield of $14 \mathrm{~kg} / \mathrm{d}$ than with $29 \mathrm{~kg} / \mathrm{d}$ ( $220 \mathrm{vs} .297$ $\mathrm{g} / \mathrm{kg}$ ). Manure N output was predicted to be 135,174 , and $213 \mathrm{~g} / \mathrm{d}$, respectively, with milk yields of 20,30 , and $40 \mathrm{~kg} / \mathrm{d}$ for a $600-\mathrm{kg}$ cow at 150 DIM (Wilkerson et al., 1997). This gives a linear decrease in manure $\mathrm{N}$ output per kilogram of milk production $(6.8,5.8$ and $5.3 \mathrm{~g} / \mathrm{kg}$, respectively). Berentsen (2003) examined effects of improving individual cow productivity on economic and environmental parameters in dairy farms in The Netherlands and concluded that an improvement in individual dairy cow productivity can considerably reduce the costs of complying with environmental legislation.

\section{Development of Prediction Equations for Manure N Output}

As discussed previously, the evaluation of the present data set indicated that forage type, proportion of dietary forage, animal breed, and lactation number had only minimal effects on the relationship between manure $\mathrm{N}$ output and $\mathrm{N}$ intake. However, this relationship was significantly influenced by dietary CP concentration, milk yield, and DIM, and the former 2 variables were therefore used as supporting predictors to $\mathrm{N}$ intake, live weight, and milk yield in the development of prediction equations for manure $\mathrm{N}$ output in lactating dairy cows.

The present study demonstrated that live weight and milk yield, either alone or combined, were poor predictors of manure $\mathrm{N}$ output in lactating dairy cows, in terms of the $\mathrm{r}^{2}$ value $(0.23$ to 0.47$)$, standard error value (70.6 to 85.6; Table 3), and poor internal validation results (Table 6). The present $r^{2}$ value $(0.23)$ in the linear relationship between manure $\mathrm{N}$ output and live weight is smaller than that (0.72) found by Smith and Frost (2000). However, the latter $\mathrm{r}^{2}$ value was derived from a data set containing not only lactating cows but also growing calves, and this may have caused biases with high-yielding cows. This clearly indicates that using live weight to predict manure $\mathrm{N}$ output in lactating dairy cows, as suggested by the American Society of Agricultural Engineers (ASAE, 2001) and Smith and Frost (2000), can produce considerable error. 
However, the prediction accuracy for manure $\mathrm{N}$ output from live weight and milk yield can be considerably improved with the addition of dietary $\mathrm{CP}$ concentration as a primary predictor. In the present study, inclusion of this variable considerably increased the $\mathrm{r}^{2}$ value to 0.75 , reduced the standard error value to 48.2 , and produced a much better prediction in the internal validation. Therefore, manure $\mathrm{N}$ output in lactating dairy cows can be predicted from the combination of live weight, milk yield, and dietary $\mathrm{CP}$ concentration.

In the present study, prediction of manure $\mathrm{N}$ output from $\mathrm{N}$ intake alone produced a much higher $\mathrm{r}^{2}$ value $(0.90$ vs. 0.23 to 0.75$)$ and a much smaller standard error value (30.6 vs. 48.2 to 85.6) than from live weight, milk yield, and dietary CP concentration (Table 3 ). The present internal validation also demonstrated that using only $\mathrm{N}$ intake to predict manure $\mathrm{N}$ output in lactating dairy cows resulted in very good prediction accuracy. Kebreab et al. (2001) reported a lower $\mathrm{r}^{2}$ value of 0.78 in the relationship between manure $\mathrm{N}$ output and $\mathrm{N}$ intake with lactating dairy cows from a small data set. Wilkerson et al. (1997) reported that the $\mathrm{R}^{2}$ value was increased from 0.65 to 0.92 when DMI was added to equations using live weight, milk yield, dietary $\mathrm{CP}$ concentration, and other variables as predictors. A similar equation using DMI, dietary CP concentration, and live weight was also reported by Nennich et al. (2005), who used the residual standard error (51.4) and interstudy standard error (56.1) to describe the accuracy of the relationship, rather than the commonly accepted $\mathrm{R}^{2}$ value. The former standard error is much higher than the standard error value (30.1) in Equation 7 (manure $\mathrm{N}$ predicted from $\mathrm{N}$ intake and live weight).

In the present study, addition of live weight and milk yield as supporting predictors to $\mathrm{N}$ intake to predict manure $\mathrm{N}$ output produced only marginal improvements in the $\mathrm{R}^{2}$ (up to 0.91) and standard error (reduced to 29.3 ) values. The internal validation also indicated that addition of live weight and milk yield had little effect on the prediction accuracy, in terms of MPE, $\mathrm{r}^{2}$ value in the relationship between predicted and actual manure $\mathrm{N}$ output, and the standard deviation value and range of the residual manure $\mathrm{N}$ output (predicted minus actual). Therefore, $\mathrm{N}$ intake alone can be used as a very accurate predictor of manure $\mathrm{N}$ output in lactating dairy cows.

\section{CONCLUSIONS}

Nitrogen intake is a very accurate predictor of manure $\mathrm{N}$ output in lactating dairy cows, with a high $\mathrm{r}^{2}$ value, a low standard error value, and an accurate internal validation. Adding live weight and milk yield as supporting predictors showed little improvement in the relationship between manure $\mathrm{N}$ output and $\mathrm{N}$ intake. Prediction of manure $\mathrm{N}$ output from live weight and milk yield, either alone or combined, can result in considerable error, but the prediction accuracy can be greatly improved by adding dietary CP concentration as a primary predictor. These 3 variables together can thus be used to predict manure $\mathrm{N}$ output when $\mathrm{N}$ intake is not available. Manure $\mathrm{N}$ output per animal can be reduced by reducing the dietary $\mathrm{CP}$ concentration, but the reduction in $\mathrm{CP}$ concentration should consider the effects on animal production and health. Increasing the milk yield per animal is another effective approach to reduce manure $\mathrm{N}$ output per unit of productivity through reducing the proportion of $\mathrm{N}$ required for maintenance.

\section{ACKNOWLEDGMENTS}

This study was funded by AgriSearch (Northern Ireland) and the Department of Agriculture and Rural Development for Northern Ireland. The authors thank their colleagues at the Agricultural Research Institute of Northern Ireland for access to their data for use in the present study.

\section{REFERENCES}

Agricultural Research Council. 1980. The Nutrient Requirements of Ruminant Livestock. Technical Review. CAB, Farnham Royal, UK.

American Society of Agriculture Engineers (ASAE). 2001. Manure production and characteristics. ASAE Standard D384.1. ASAE, St. Joseph, MI.

Berentsen, P. B. M. 2003. Effects of animal productivity on the costs of complying with environmental legislation in Dutch dairy farming. Livest. Prod. Sci. 84:183-194.

Børsting, C. F., T. Kristensen, L. Misciattelli, T. Hvelplund, and M. R. Weisbjerg. 2003. Reducing nitrogen surplus from dairy farms. Effects of feeding and management. Livest. Prod. Sci. 83:165-178.

Bruchem, J. V., M. W. Bosch, and S. Oosting. 1991. Nitrogen efficiency of grassland-based dairy farming-New perspectives using an integrated approach. Pages 99-101 in Utilisation of Local Feed Resources by Dairy Cattle. G. E. Groen, and J. V. Bruchem, ed. EAAP Publ. No. 84. Wageningen Press, The Netherlands.

Castillo, A. R., E. Kebreab, D. E. Beever, and J. France. 2000. A review of efficiency of nitrogen utlisation in lactating dairy cows and its relationship with environmental pollution. J. Anim. Feed Sci. 9:1-32.

European Union. 1991. Implementation of Nitrates Directive. http:// ec.europa.eu/environment/water/water-nitrates/index_en.html

Hof, G., and S. Tamminga. 1994. Feeding management to reduce nitrogen losses in dairy cows. Pages 149-153 in Biological Basis of Sustainable Animal Production. Proc. 4th Zodiac Symp. Wageningen, The Netherlands.

Kebreab, E., J. France, D. E. Beever, and A. R. Castillo. 2001. Nitrogen pollution by dairy cows and its mitigation by dietary manipulation. Nutrient Cycling Agroecosyst. 60:275-285.

Klausner, S. D. 1993. Mass nutrient balances on dairy farms. Pages 126-129 in Proc. Cornell Nutr. Conf. Feed Manuf. Rochester, NY. Cornell Univ., Ithaca, NY.

Korevaar, H. 1992. The nitrogen balance on intensive Dutch dairy farms: A review. Livest. Prod. Sci. 31:17-27. 
Mayne, C. S., and F. J. Gordon. 1984. The effect of type of concentrate and level of concentrate feeding on milk production. Anim. Prod. 39:65-76.

Nennich, T. D., J. H. Harrison, L. M. VanWieringen, D. Meryer, A. J. Heinrichs, W. P. Weiss, N. R. St-Pierre, R. L. Kincaid, D. L. Davidson, and E. Block. 2005. Prediction of manure and nutrient excretion from dairy cattle. J. Dairy Sci. 88:3721-3733.

Mulvanny, P. M. 1977. Dairy cow condition scoring. Paper No. 4468. Natl. Inst. Res. Dairying, Reading, UK.

Smith, K. A., and J. P. Frost. 2000. Nitrogen excretion by farm livestock with respect to land spreading requirements and controlling nitrogen losses to ground and surface waters. Part 1: Cattle and sheep. Livest. Prod. Sci. 71:173-181.

Tamminga, S. 1992. Nutrition management of dairy cows as a contribution to pollution control. J. Dairy Sci. 75:345-357.

Wilkerson, V. A., D. R. Mertens, and D. P. Casper. 1997. Prediction of excretion of manure and nitrogen by Holstein cows. J. Dairy Sci. 80:3193-3204.

Van Horn, H. H., A. C. Wilkie, W. J. Power, and R. A. Nordstedt. 1994. Components of dairy manure management systems. J. Dairy Sci. 77:2008-2030. 